\title{
USAGE OF WASTE ACTIVE SLUDGE OBTAINED FROM A MEMBRANE BIOREACTOR SYSTEM AS A LOW- COST BIOSORBENT FOR REMOVAL OF CU (II) IONS
}

\author{
Ülküye Dudu GÜL ${ }^{1 *}$, Cağlayan AÇIKGÖZ2 ${ }^{2}$ Hülya SİLAH ${ }^{3}$ \\ ${ }^{1}$ Vocational School of Health Services, Biotechnology Application and Research Center, Bilecik Seyh Edebali University, \\ 11210, Bilecik, Turkey \\ ${ }^{2}$ Faculty of Engineering, Department of Chemical \&Process Engineering Bilecik Seyh Edebali University, Turkey \\ ${ }^{3}$ Department of Chemistry, Faculty of Art \& Science, Bilecik Seyh Edebali University, 11210 Bilecik, Turkey
}

\begin{abstract}
This study aims to suggest an inexpensive adsorbent. It is also planned to reuse the waste sludge of the membrane bioreactor (MBR) system. For this reason, copper biosorption capacity of waste sludge compost of fungal biomass from an MBR unit was investigated. The effects of $\mathrm{pH}(2,4,6$, and 8), contact time (1- 24h), and $\mathrm{Cu}$ (II) concentration $(9.74$ to $98.21 \mathrm{mg} / \mathrm{L})$ were tested at batch scale level experiments. To describe the equilibrium isotherms, the Langmuir and Freundlich models were used. Also, kinetic properties were determined as pseudo-first-order and pseudo-second-order models. To determine the functional groups of adsorbent, Fourier Transform Infrared Spectrophotometer (FTIR) analysis was done. The maximum Cu (II) removal was 89.65 $\%$ at $\mathrm{pH}$ 4. The maximum $\mathrm{Cu}$ (II) uptake capacity of adsorbent was found as $14.20 \mathrm{mg} / \mathrm{g}$. The results of this study showed that the dried active sludge, a waste of MBR system, was an efficient and low-cost adsorbent for removal of $\mathrm{Cu}$ (II) from industrial effluents.
\end{abstract}

Key words: adsorption, $\mathrm{Cu}$ (II) removal, waste active sludge, wastewater treatment

\section{INTRODUCTION}

Heavy metal pollution represents an important problem for the aqueous environment. In addition to this, heavy metals have toxic effects on living organisms [1]. Most of the industrial activities like metal plating and mining consume large volumes of heavy metal contaminated water and these heavy metals such as copper $\mathrm{Cu}(\mathrm{II})$ are hazardous. For instance, $\mathrm{Cu}(\mathrm{II})$ does not degrade easily in the environment and can be harmful to human health. The levels of $\mathrm{Cu}(\mathrm{II})$ ions above $1.3 \mathrm{mg} / \mathrm{L}$ cause stomach and intestinal problems in humans. Unfortunately, waste streams from industries contaminated with $\mathrm{Cu}$ (II) may contain up to 500 $\mathrm{mg} / \mathrm{L} \mathrm{Cu}(\mathrm{II})$ [2]. So the effluents containing heavy metals like $\mathrm{Cu}$ (II) need to be treated before discharging to the aqueous environment. The removal of heavy metals is very important due to their destructive effects on the environment and human health. A variety of conventional methods such as chemical precipitation, ion exchange, filtration, solvent extraction, reverse osmosis, and membrane technologies are recommended to remove heavy metals from aqueous solutions [3]. While the concentration of heavy metals is ranged from 1 to $100 \mathrm{mg} / \mathrm{L}$, the conventional methods are not sufficient for removal of the heavy metals. Also, these methods have some disadvantages such as producing toxic chemical sludge and not being eco-friendly. Adsorption is reported as an effective technology for the removal of pollutants like heavy metals from aqueous solutions [3, 4]. The advantage of adsorption is described as effective in removing heavy metals via the utilization of cheap adsorbent [5]. Most of the researches is still focusing on searching cheap and effective adsorbents for the removal of heavy metals $[6,7]$. A variety of adsorbents such as microorganisms, plant by-products, and waste materials have been used to remove heavy metals from aqueous medium [8, 9]. Fungal biosorbents have been proved efficient and economical for the removal of metal ions from aqueous solutions $[10,11]$. The structure of the fungal cell wall has excellent metal-binding properties. However, there isn't enough information about the usage of waste fungal biomass for the removal of heavy metal. The membrane bioreactor (MBR) systems present effective pollutant removal and excellent effluent quality for the treatment of industrial wastewater $[12,13]$. Although active sludge technology is widely used all over the world, the waste sludge of a bioreactor unit is considered as an environmental problem because of causing solid waste pollution. For environmental and ecological reasons, the disposal of this sludge has become immensely important. Samples of active sludge were collected from the MBR system as solid waste and reused as an adsorbent in this study. The aim of this work is to reuse the waste sludge compost of fungal biomass obtained from the MBR and to examine the potential usage of this dried waste as a low-cost adsorbent. This study is intended to demonstrate the technical feasibility of simple and low-cost procedure to remove toxic heavy metals such as copper from aqueous solutions. To our knowledge, this is the first report correlating with copper removal by using waste sludge of an MBR.

\section{MATERIALS AND METHODS}

\section{Preparation of Heavy Metal Solution}

The stock $\mathrm{Cu}$ (II) solution was prepared by dilution of $\mathrm{CuSO}_{4}$ (Merck) having a final concentration of $1 \mathrm{~g} / \mathrm{L}$ of $\mathrm{Cu}$ (II). Appropriate volumes of the stock solutions were added into the aqueous solutions in the experimental series.

\section{Preparation of Adsorbent}

Fungal strains Aspergillus versicolor and Rhizopus arrhizus were obtained from Ankara University Biology Department Biotechnology Laboratory Culture Collection. The mixed cultures were inoculated into the MBR System in order to decolorize the textile dyes in another study. The active sludge (containing Aspergillus versicolor and Rhizopus arrhizus), used in this study, was used for the decolorization of simulated textile wastewater in MBR in our previous study [14]. After decolorization process, the active waste sludge containing $R$. arrhizus and A. versicolor was drained from the bioreactor system, and washed with distilled water, then dried at $80^{\circ} \mathrm{C}$. The dried waste sludge was smashed and, a known amount of 
powdered waste sludge was used as an adsorbent for adsorption studies. The dried adsorbent was sieved by using an $80 \mu \mathrm{m}$ sieve. All experiment series performed with the solutions contained $0.5 \mathrm{~g} / \mathrm{L}$ of the adsorbent.

\section{Adsorption Studies}

Adsorption studies were carried out by the batch technique in $250 \mathrm{~mL}$ flasks containing $200 \mathrm{~mL}$ of $\mathrm{Cu}$ (II) including synthetic solutions at the desired level of each component at the beginning of the adsorption. The flasks were continuously agitated on a shaker at a constant shaking rate of $1.118 \times 10 \mathrm{~g}$ for 24 hours to ensure that equilibrium was reached. To determine the contact time on adsorption, the waste fungal biomass (Dry weight: $0.5 \mathrm{~g} / \mathrm{L}$ ) was added into flasks contained $200 \mathrm{~mL}$ distilled water with $49.40 \mathrm{mg} / \mathrm{L}$ $\mathrm{Cu}(\mathrm{II})$ at $\mathrm{pH} 2$ for 0 to 1440 minutes. The effect of $\mathrm{pH}$ was determined in flasks contained distilled water with 49.40 $\mathrm{mg} / \mathrm{L} \mathrm{Cu}$ (II) at $\mathrm{pH} \mathrm{2,} \mathrm{4,} \mathrm{6,} \mathrm{and} \mathrm{8.} \mathrm{To} \mathrm{examine} \mathrm{the} \mathrm{effect} \mathrm{of}$ $\mathrm{Cu}$ (II) concentrations on adsorption the adsorbent was added into flasks contained distilled water with 9.74, 45.96, 76.49, and $98.21 \mathrm{mg} / \mathrm{L} \mathrm{Cu}(\mathrm{II})$. The $200 \mathrm{~mL}$ distilled water flask containing only $\mathrm{Cu}(\mathrm{II})$ without adsorbent was used as a control. Samples $(3 \mathrm{~mL})$ were taken every 2 hours and centrifuged at $5.59 \times 10-2 \mathrm{~g}$ for $5 \mathrm{~min}$ (Hettich EBA12 model centrifuge).

\section{Analytical Methods}

A $3 \mathrm{~mL}$ of sample was taken from each flask, every 2 hours and the concentration of $\mathrm{Cu}$ (II) in the supernatant was determined by atomic absorption spectrometry (GBC933AA). The $200 \mathrm{~mL}$ of distilled water flask containing only $\mathrm{Cu}(\mathrm{II})$ without adsorbent was used as a control. Experiments were conducted in triplicate and the results are the average of triplicate measurements. Finally, the removal percentage (Cu (II) Removal \%) and uptake capacity (qm, $\mathrm{mg} / \mathrm{g}$ ) were calculated by Equations (1) and (2), respectively.

$$
\begin{array}{cc}
\% \mathrm{Cu}(\text { II }) \text { Removal }=\frac{C_{0} C_{f}}{C_{0}} \times 100 \% & \text { Eq. (1) } \\
q_{m}=\frac{\left(C_{0}-C_{f}\right) V}{W} & \text { Eq. (2) }
\end{array}
$$

In this equation; $\mathrm{C} 0(\mathrm{mg} / \mathrm{L})$ : initial concentration of $\mathrm{Cu}$ (II) ion, $\mathrm{Cf}(\mathrm{mg} / \mathrm{L})$ : the residual concentration of $\mathrm{Cu}$ (II) ion, $\mathrm{V}$ $(\mathrm{L})$ : the solution volume, $\mathrm{W}(\mathrm{g})$ : the dosage of biosorbent

\section{Statistical analysis}

The experimental analyzes were done triplicate. SPSS 17 was applied to analyze the data and ANOVA (one-way) was used to compare average values. Correlation coefficients were calculated by using the Microsoft Excel package.

\section{Fourier Transform Infrared Spectrophotometer (FTIR)} Analysis

The functional groups on the surface of waste active sludge in the absence and presence of $\mathrm{Cu}$ (II) were identified by using the FTIR technique. FTIR spectra were recorded by the Perkin Elmer (Spectrum 100) spectrophotometer in the region of $650-4000 \mathrm{~cm}^{-1}$. Dry powdered samples of waste fungal biomass un-loaded and loaded with $\mathrm{Cu}$ (II) ions were prepared and used in FTIR analysis.

\section{RESULTS AND DISCUSSION \\ The Effect of Contact Time}

The effect of treatment time on the concentration of $\mathrm{Cu}$ (II) in aqueous solution is given in Fig. 1. The $\mathrm{Cu}$ (II) uptake process was reached the plateau values within $480 \mathrm{~min}$. After 480 minutes, the $\mathrm{Cu}$ (II) concentration wasn't considerable change in the aqueous solution so it was considered as the optimum contact time.

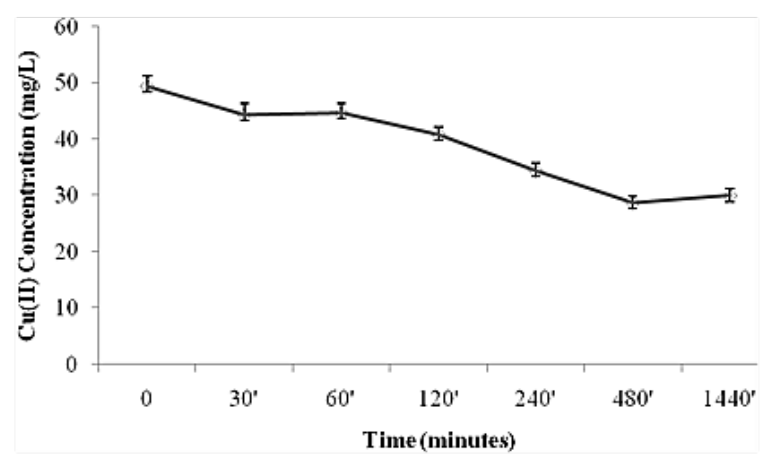

Figure 1. Effect of contact time on the concentration of $\mathrm{Cu}$ (II) in aqueous solution (Co:49.40 mg/L; $\mathrm{pH}: 2$; adsorbent dosage: $0.5 \mathrm{~g} / \mathrm{L}$; $\mathrm{p}=.05, \mathrm{df}=3$ ). Error bars represent the standard error of the mean.

\section{The Effect of pH}

$\mathrm{pH}$ is an important factor affecting heavy metal adsorption. The $\mathrm{pH}$ value affects the biosorption process by both protonation or deprotonation of the functional groups on the adsorbent surface and the ionization potential of the heavy metal in solution [15]. Fig. 2 indicates the effect of initial solution $\mathrm{pH}$ on the removal of $\mathrm{Cu}$ (II) from aqueous solution at $49.40 \mathrm{mg} / \mathrm{L}$ initial $\mathrm{Cu}$ (II) concentration and $25 \mathrm{oC}$. The highest $\mathrm{Cu}$ (II) removal percentage was obtained at $\mathrm{pH} 4$ (Fig. 2). Recently, Xie et al. (2017) showed that the functional groups on the adsorbent had an important role in copper uptake [16]. It was verified that the surface of waste active sludge (contained fungal biomass) had negatively charged sites like carboxylate groups having weaker but acidic groups dominantly. The $\mathrm{Cu}$ (II) ions were mainly adsorbed on these acid sites. At low $\mathrm{pH}$, the surface of waste active sludge would also be surrounded by hydronium ions which decrease the $\mathrm{Cu}$ (II) interaction with binding sites of the dried waste active sludge by greater repulsive forces. As a result, the optimal $\mathrm{pH}$ value for $\mathrm{Cu}$ (II) biosorption was chosen as 4.0 and the continuous experiments were performed at this $\mathrm{pH}$ value. Gochev et al. (2012) recently showed that the dead biomass of Trametes versicolor removed $\mathrm{Cu}$ (II) ions maximally at $\mathrm{pH} 4$ [17]. The results of $\mathrm{pH}$ experiments were fitted with the literature. The $\mathrm{pH}$ value 4 was selected for continuing experiments.

\section{The Effect of Initial $\mathrm{Cu}$ (II) Concentration}

The $\mathrm{Cu}$ (II) removal values at different initial metal ion concentrations are given in Figure 3. It was clear that the removal capacity of dried active sludge for $\mathrm{Cu}$ (II) decreased with increasing initial metal concentration. The removal rate of $\mathrm{Cu}$ (II) decreased from 89.65 to $6.22 \%$ with increasing initial $\mathrm{Cu}$ (II) concentration from 9.74 to $98.21 \mathrm{mg} / \mathrm{L}$ (Fig. 3). The augmentation of initial $\mathrm{Cu}$ (II) concentrations resulted in reducing the metal removal percentage. The initial $\mathrm{Cu}$ (II) concentration studies showed that a finite number of surface binding sites on the active sludge surface were saturated by higher $\mathrm{Cu}$ (II) concentrations.

At higher concentrations, the removal of metals is related to the initial metal concentration because available sites for metal biosorption become fewer. According to these results, the treatment efficiency can be increased by diluting the wastewater containing high metal ion concentrations in wastewater treatment systems. Recently, the researchers about heavy metal removal by low-cost adsorbents gain importance. The $\mathrm{Cu}$ (II) removal by inexpensive adsorbents such as olive mill solid residue, tree fern, wheat shell, and grape stalks wastes from aqueous solutions were investigated previously. Copper uptake capacities of olive mill solid residue, tree fern, wheat shell, and grape stalk wastes were shown as 13.5 [18], 10.6 [19], 10.8 [20] and 10.1 [21] $\mathrm{mg} / \mathrm{g}$, respectively. Recently, Abdel-Galil et al. (2016) showed that the maximum sorption capacity (qm) for the Leucaena waste biomass 
sorbent toward $\mathrm{Cu}$ (II) was $7.89 \mathrm{mg} / \mathrm{g}$ [22]. In this study, maximum $\mathrm{Cu}$ (II) uptake capacity of dried waste active sludge compost of fungal biomass obtained from MBR was calculated as $14.20 \mathrm{mg} / \mathrm{g}$. The effect of initial $\mathrm{Cu}$ (II) concentration experiments showed that the waste active sludge used in this study performed the best copper uptake capacity while comparing other reported ones.

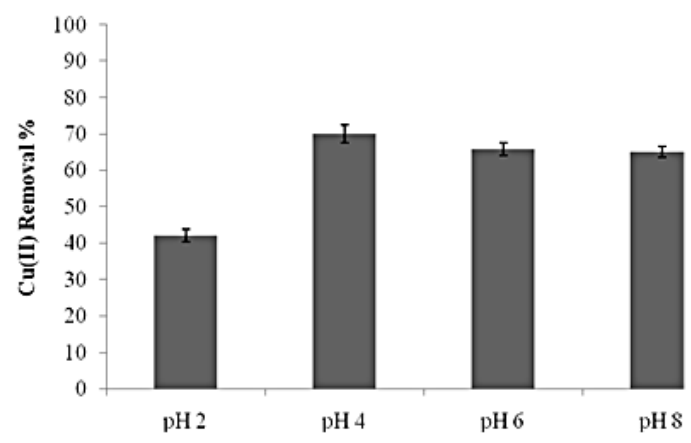

Figure 2. Effect of $\mathrm{pH}$ on the removal of $\mathrm{Cu}$ (II) by waste fungal biomass (Co: $49.40 \mathrm{mg} / \mathrm{L} ; \mathrm{pH}: 2$; contact time: 1440 ; adsorbent dosage: $0.5 \mathrm{~g} / \mathrm{L} ; \mathrm{p}=.05, \mathrm{df}=3$ ). Error bars represent the standard error of the mean.

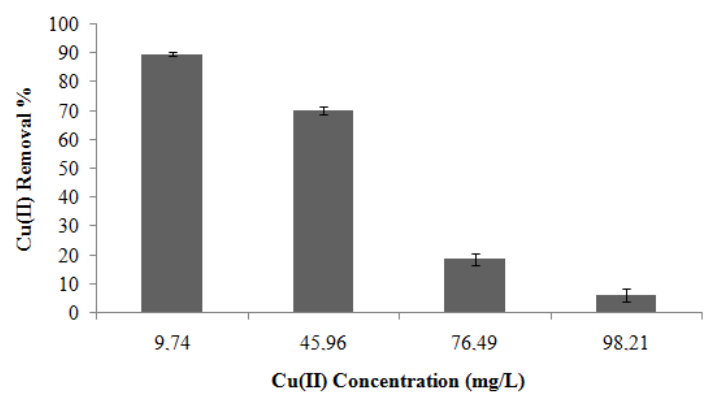

Figure 3. Effect of initial $\mathrm{Cu}$ (II) concentration on the removal of $\mathrm{Cu}$ (II) by waste fungal biomass ( $\mathrm{pH}: 2$; contact time: 1440 ; adsorbent dosage: $0.5 \mathrm{~g} / \mathrm{L} ; \mathrm{p}=.05, \mathrm{df}=3$ ). Error bars represent the standard error of the mean.

\section{Biosorption Isotherms}

The value of adsorption isotherms obtained for $\mathrm{Cu}$ (II) uptake was plotted using Langmuir and Freundlich equations. The widely used Langmuir isotherm assumes monolayer adsorption onto a solid surface [23] which is given as;

$$
\frac{C_{e}}{q_{e}}=\frac{C_{e}}{q_{m}}+\frac{1}{q_{m} K_{L}}
$$

In this equation; $\mathrm{q}_{\mathrm{e}}(\mathrm{mg} / \mathrm{g})$ : the amount of $\mathrm{Cu}$ (II) adsorbed per unit weight of adsorbent at equilibrium, $\mathrm{q}_{\mathrm{m}}$ $(\mathrm{mg} / \mathrm{g})$ : the maximum $\mathrm{Cu}$ (II) uptake per unit mass of adsorbent, $\mathrm{K}_{\mathrm{L}}(\mathrm{L} \mathrm{mg} / \mathrm{g})$ : the Langmuir constant related to the energy of sorption which quantitatively reflects the affinity between the adsorbent and adsorbate, $\mathrm{Ce}(\mathrm{mg} / \mathrm{L})$ : the equilibrium concentration of adsorbate.

The values of $\mathrm{q}_{\mathrm{m}}$ and $\mathrm{K}_{\mathrm{L}}$ were calculated from the slope and intercept of the graph using Eq.(3).

The Freundlich equation [24] is used for heterogeneous surface energy systems and given as;

$$
\log q_{e}=\log K_{F}+\frac{1}{n} \log C_{e}
$$

Freundlich linear plot of $\log \mathrm{q}_{\mathrm{e}}$ versus $\log$ Ce, respectively.

The comparison of the $\mathrm{R}^{2}$ values showed that the Langmuir model fits better with the experimental data than the Freundlich one (Fig. 4; Table 1) for waste active sludge. The Langmuir equation is used for homogeneous surfaces. Similarly, Subbaiah et al. (2011) reported that the Langmuir isotherm was fitted with the $\mathrm{Cu}$ (II) biosorption by dead Trametes versicolor biomass [25].
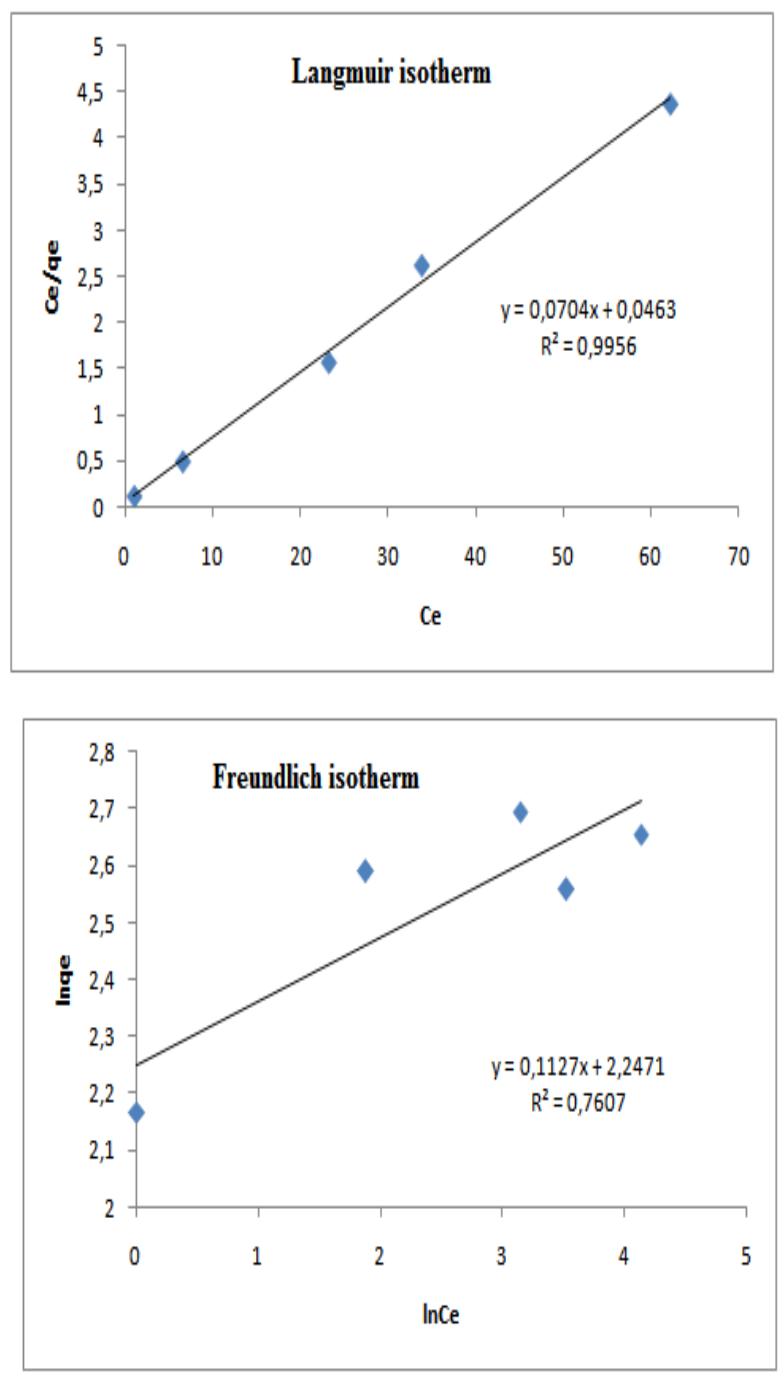

Figure 4. Adsorption isotherm graphics

Recently, Kan et al. (2015) showed that $\mathrm{Cu}$ (II) adsorption on mushroom biomass equilibrium is best described by the Langmuir model [26]. The adsorption on the waste active sludge contained fungal biomass was fitted with the Langmuir model in this study. The adsorption capacity, $\mathrm{q}_{\mathrm{m}}$, estimated from the Langmuir model for $\mathrm{Cu}$ (II) is $14.20 \mathrm{mg} / \mathrm{g}$. When the adsorption capacity of the MBR is compared to the removal of $\mathrm{Cu}$ (II) ions with other biosorbents, it is seen that the MBR system is a good alternative method for copper removal. Liang et al. isolated an indigenous $\mathrm{Cu}$-resistant bacteria strain from heavy metal-contaminated soil and used this bacterial strain as a biosorbent to remove $\mathrm{Cu}$ (II) ions from aqueous solution. They found that the maximum sorption capacity of this biosorbent was $12.6 \mathrm{mg} / \mathrm{g}[5]$.

\begin{tabular}{cccccc}
\hline \multicolumn{3}{c}{ Langmuir } & \multicolumn{3}{c}{ Freundlich } \\
$\boldsymbol{q}_{\boldsymbol{m}}$ & $\mathbf{K}_{\mathbf{L}}$ & $\mathbf{R}^{2}$ & $\mathbf{N}$ & $\mathbf{K}_{\mathbf{F}}$ & $\mathbf{R}^{2}$ \\
$(\mathrm{mg} / \mathrm{g})$ & $(\mathrm{Lmg} / \mathrm{g})$ & & & $(\mathrm{L} / \mathrm{g})$ & \\
\hline 14.20 & 1.52 & 0.9956 & 8.87 & 9.46 & 0.7607
\end{tabular}

Table 1 Langmuir and Freundlich Constants for $\mathrm{Cu}$ (II) 
Biosorption by Waste Fungal Biomass

\section{Biosorption Kinetics}

The kinetic rates in the present study were modeled using pseudo-first and second-order models. The pseudo-first-order model was defined as follows;

$$
\log \left(q_{e} \mid-q_{t}\right)=\frac{-k_{1}}{2.303 t}+\log q_{e}
$$

In this equation; $\mathrm{q}_{\mathrm{t}}(\mathrm{mg} / \mathrm{g})$ : the amounts of $\mathrm{Cu}$ (II) adsorbed at time $\mathrm{t}, \mathrm{qe}(\mathrm{mg} / \mathrm{g})$ : the amounts of $\mathrm{Cu}(\mathrm{II})$ adsorbed at equilibrium, $\mathrm{k}_{1}(1 / \mathrm{min})$ : the rate constant of pseudo-first-order equation. The slope and intercept of the graph of $\log \left(\mathrm{q}_{\mathrm{e}}-\mathrm{q}_{\mathrm{t}}\right)$ versus $\mathrm{t}$ correspond to the value of constants $\mathrm{k}_{1}$ and $\mathrm{q}_{\mathrm{e}}$ respectively.

The pseudo-second-order model can be expressed by the following equation;

$$
\frac{t}{q_{t}}=\frac{1}{k_{2} q_{e}^{2}}+\frac{1}{q_{e}} t
$$

In this equation, $\mathrm{k}_{2}$ is the rate constant of the pseudo-secondorder equation.

The applicability of two kinetic models; pseudo-first order model and pseudo-second-order model were used to investigate the kinetics of $\mathrm{Cu}$ (II) adsorption onto waste active sludge compost of fungal biomass. The graphics for adsorption kinetics are given in Fig. 5.
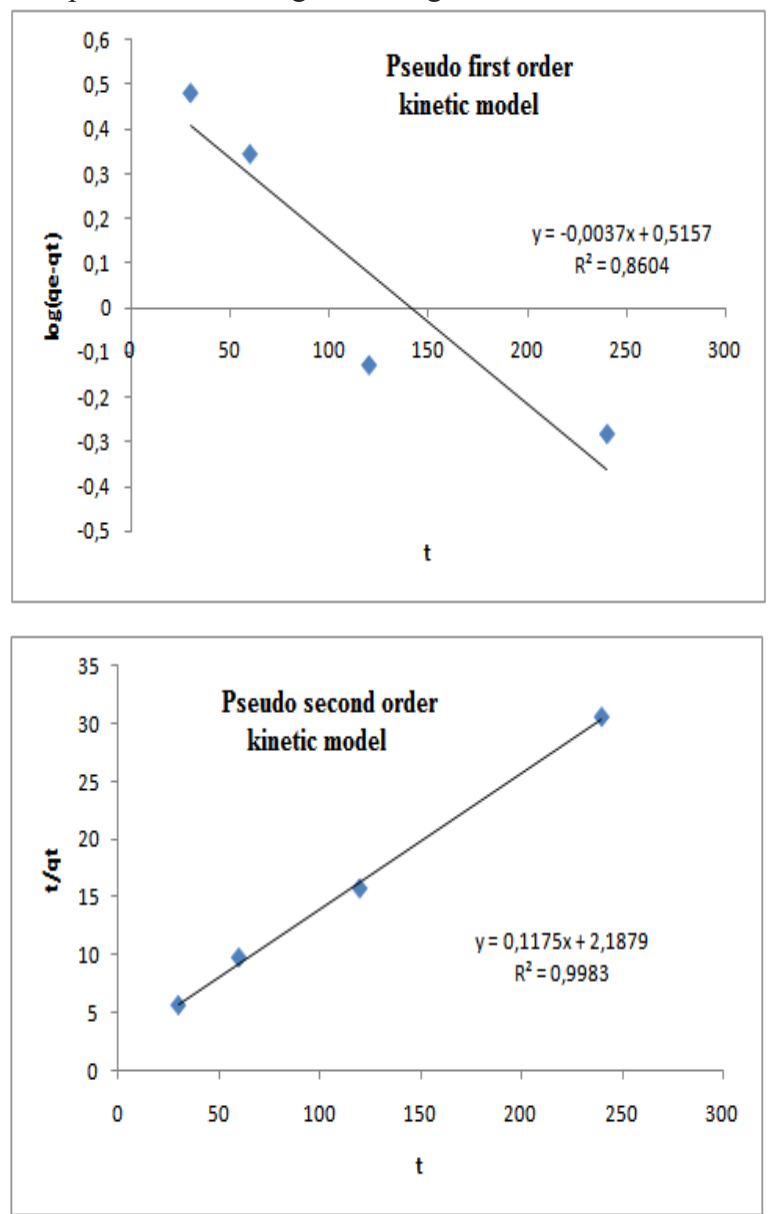

Figure 5. Adsorption kinetic graphics

As shown in Table 2, the experimental qeexp value did not agree with the calculated qecal from the pseudo-first-order model for waste fungal biomass. The qecal value of the pseudo-second-order model was near with the qeexp value and the correlation constant of the pseudo-second-order model was higher than the pseudo-first-order model. According to these results, the biosorption of $\mathrm{Cu}$ (II) by the waste active sludge was compatible with the pseudo-secondorder model. This result was similar to the results of the study of Subbaiah et al. (2011) showing the $\mathrm{Cu}$ (II) biosorption properties of T. versicolor [25].

Table 2 Kinetic Parameters for The Adsorption of $\mathrm{Cu}$ (II) onto Waste Fungal Biomass

\begin{tabular}{cccccccccc}
\hline \multicolumn{4}{c}{ Pseudo-first-order model } & \multicolumn{5}{c}{ Pseudo-second-order model } \\
\hline$e_{c a l}$ & $q e_{\text {exp }}$ & $\mathbf{k}_{1}$ & $\mathbf{R}^{2}$ & $q e_{c a l}$ & $q e_{\text {exp }}$ & $\mathbf{k}_{2}$ & $\mathbf{R}^{2}$ \\
\hline 3.278 & 8.37 & $8.52 \times 10^{-3}$ & 0.8604 & 8.51 & 8.37 & $6.52 \times 10^{-3}$ & 0.9983 \\
\hline
\end{tabular}

\section{FTIR Analysis}

To explain the adsorption mechanism; it is important to identify the functional groups of adsorbents that are responsible for the biosorption process of metal ions. FTIR spectroscopy gives essential information related to the changes of fungal biomass surface before and after the adsorption process. FTIR spectrums of nature and copper loaded waste active sludge are given in Fig. 6. The wideband approximately between 3500$3000 \mathrm{~cm}^{-1}$ presents to bonds of $-\mathrm{OH}$ and $-\mathrm{NH}$ groups. As seen in Fig. 6, these bands were shown at $3274 \mathrm{~cm}-1$ before adsorption but after biosorption, it was shifted to $3280 \mathrm{~cm}^{-1}$. Also, the band at $1538 \mathrm{~cm}^{-1}$, was related to amide bond, was shifted to $1529 \mathrm{~cm}^{-1}$ after adsorption and the intensity of this band was increased. As seen in Fig. 6, the bands were shown at $1016.5 \mathrm{~cm}^{-1}$ before adsorption but after biosorption, this band was shifted to $1021 \mathrm{~cm}^{-1}$ and the intensity of the peak was increased. Meanwhile, the change in wavenumber of functional groups and absorption intensity is related to the interaction of copper ions with active sites of waste active sludge containing fungal biomass. It is considered that the bonds between copper and active sites of waste active sludge are formed due to electrostatic interaction mechanisms [27, 28].

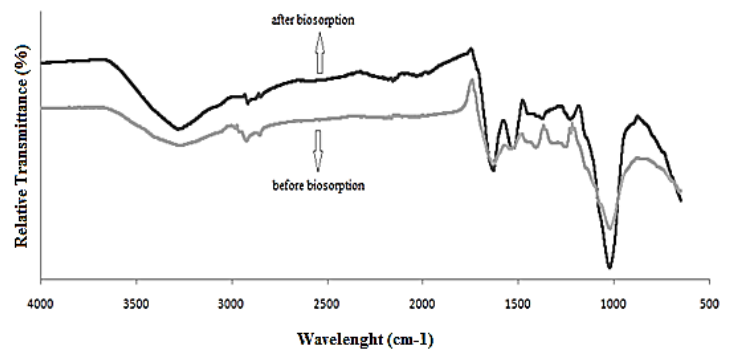

Figure 6. FTIR spectra of waste fungal biomass before and after biosorption

\section{CONCLUSIONS}

Recent studies focus on the requirement of low-cost biosorbents and, waste management is also a concerning issue today. The purpose of this study is to recommend an alternative way the elimination of the waste of MBR unit and re-use this waste as a low-cost biosorbent. The results of the current study show that the $\mathrm{Cu}$ (II) removal was reached $89.65 \%$, maximally. The waste active sludge containing fungal biomass has been introduced as a successful adsorbent for the removal of $\mathrm{Cu}$ (II) ions from aqueous solutions in this study. Since the active sludge compost of fungal biomass was a solid waste of MBR which was used for decolorization of textile dyes, used in this study, it was freely, abundantly, and locally available and this adsorbent is expected to be economically viable for the treatment of metal-containing wastewater.

\section{REFERENCES}

[1] Shao N, Tang S, Liu Z, Li L, Yan F, Liu F, Li S, Zhang Z. 2018. Hierarchically Structured Calcium Silicate Hydrate-Based Nanocomposites Derived from Steel Slag for Highly Efficient Heavy Metal Removal from Wastewater. 
ACS Sustainable Chemistry \& Engineering, 6(11), 1492614935.

[2] Dermentzis K, Davidis A, Papadopoulou D, Christoforidis A, Ouzounis K. 2009. Copper removal from industrial wastewaters by means of electrostatic shielding driven electrodeionization. Journal of Engineering Science and Technology Review, 2,131-136.

[3] Li M, Wei D, Liu T, Liu Y, Yan L, Wei Q, Du B, $\mathrm{Xu}$ W. 2019. EDTA functionalized magnetic biochar for $\mathrm{Pb}$ (II) removal: Adsorption performance, mechanism and SVM model prediction. Sep Purif Technol, 227(115696),110.

[4] Liu W, Wang D, Soomro RA, Fu F, Qiao N, Yu Y, Wang R, Xu B. 2019. Ceramic supported attapulgitegraphene oxide composite membrane for efficient removal of heavy metal contamination. J Membrane Sci, 591(117323), 1-9.

[5] Liang Y, Chen JQ, Mei J, Chang JJ, Wang QY, Wan GS, Yin BY. 2019. Characterization of $\mathrm{Cu}$ and $\mathrm{Cd}$ biosorption by Pseudomonas sp. Strain DC-B3 isolated from metal mine soil. Int J Environ Sci Te, 16, 4035-4046.

[6] Ahluwalia SS, Goyal D, 2007. Microbial and plant derived biomass for removal of heavy metals from waste water. Bioresour Technol, 98, 2243-2257.

[7] Ergtugay N, Bayhan YK. 2008. Biosorption of $\mathrm{Cr}$ from aqueous solutions by biomass of Agaricus bisporus. $\mathrm{J}$ Hazard Mater, 154, 432-439.

[8] Hossain A, Bhattacharyya SR, Aditya G. 2015. Biosorption of Cadmium by Waste Shell Dust of Fresh Water Mussel Lamellidens marginalis: Implications for Metal Bioremediation. ACS Sustainable Chemistry \& Engineering, 3(1), 1-8.

[9] Wang N, Qui Y, Xiao T, Wang J, Chen Y, Xu X, Kang Z, Fan L, Yu H. 2019. Comparative studies on Pb(II) biosorption with three spongy microbe-based biosorbents: High performance selectivity and application. J Hazard Mater, 373, 39-49.

[10] Yan G, Viraraghavan T. 2003. Heavy metal removal from aqueous solution by fungus Mucor rouxii. Water Res, 37, 4486- 4496.

[11] Kankilic GB, Metin AU, Aluc Y, Bozkaya O. 2018. Bioremoval of mercury (II) from aqueous solutions by Phragmites australis: Kinetic and equilibrium studies. J Disper Sci Technol, 39, 1790-1799.

[12] Aftab B, Khan SJ, Maqbool T, Hankins NP. 2017. Heavy metals removal by osmotic membrane bioreactor (OMBR) and their effect on sludge properties. Desalination, 403, 117-127.

[13] Hai FI, Yamamoto K, Fukushi K. 2006. Development of a submerged membrane fungi reactor for textile wastewater treatment. Desalination, 192, 315-322.

[14] Açikgoz Ç, Gül ÜD, Özan K, Borazan A. 2016. Degradation of Reactive Blue by the mixed culture of Aspergillus versicolor and Rhizopus arrhizus in membrane bioreactor (MBR) system. Desalin Water Treat, 57, 37503756.

[15] Aksu Z, Ișoğlu A. 2005. Removal of copper(II) ions from aqueous solution by biosorption onto agricultural waste sugar beet pulp. Process Biochem, 40, 3031-3044.

[16] Xie R, Jin Y, Chen, Y, Jiang W. 2017. The importance of surface functional groups in the adsorption of copper onto walnut shell derived activated carbon. Water Sci Technol, 7, 3022-3034.

[17] Gochev V, Velkova Z, Stoytcheva M, Yemendzhiev H, Aleksieva Z, Krastanov A. 2012. Biosorption of $\mathrm{Cu}(\mathrm{II})$ from aqueous solutions by immobilized mycelium of Trametes versicolor. Biotechnology \& Biotechnological Equipment, 26, 33653370.
[18] Pagnanelli F, Toro L, Vegilo F. 2002. Olive mill solid residues as heavy metal sorbent material: a preliminary study. Waste Manage, 22, 901-907.

[19] Ho YS. 2003. Removal of copper ions from aqueous solution by tree fern. Water Res, 37, 2323-2330.

[20] Basci N, Kocadagistan E, Kocadagistan B. 2004. Biosorption of copper(II) from aqueous solutions by wheat shell. Desalination, 164, 135- 140.

[21] Villaescusa I, Fiol N, Martinez M, Miralles N, Poch J, Serarols J. 2004. Removal of copper and nickel ions from aqueous solutions by grape stalks wastes. Water Res, 3, 9921002.

[22] Abdel-Galil EA, Rizk HE, Mostafa AZ. 2016. Isotherm, kinetic, and thermodynamic studies for the sorption of $\mathrm{Cu}(\mathrm{II})$ and $\mathrm{Pb}(\mathrm{II})$ by activated carbon prepared from Leucaena plant wastes. Particul Sci Technol, 34, 540-551.

[23] Langmuir I. 1918. The adsorption of gases on plane surfaces of glass, mica, and platinum. J Am Chem Soc, 40, 1361- 1368.

[24] Freundlich H. 1906. Adsorption in solution. Phys Chem Soc, 40, 1361- 1368.

[25] Subbaiah MV, Vijaya Y, Reddy AS, Yuvaraja G, Krishnaiah A. 2011. Equilibrium, kinetic and thermodynamic studies on the biosorption of $\mathrm{Cu}$ (II) onto Trametes versicolor biomass. Desalination, 276, 310-316.

[26] Kan SH, Sun BY, Xu F, Song QX, Zhang SF. 2015. Biosorption of aquatic copper (II) by mushroom biomass Pleurotus eryngii: kinetic and isotherm studies. Water Sci Technol, 71, 283-288.

[27] Michalak I, Chojnacka K, Witek-Krowiak A. 2013. State of the Art for the biosorption process- a review. Applied Biochemical Biotechnology, 170, 1389- 1416.

[28] Salvi NA, Chattopadhyay S. 2017. Biosorption of Azo dyes by spent Rhizopus arrhizuss biomass. Applied Water Science, 7, 3041-3054. 